Revue bibliographique pour le domaine irano-aryen

Volume 37-38-39 | 2018

Comptes rendus des publications de 2014-2016

\title{
Touraj Daryaee. “The Last Ruling Woman of Ērānšahr: Queen Āzarmīgduxt"
}

\section{Rika Gyselen}

\section{(2) OpenEdition \\ 1 Journals}

\section{Édition électronique}

URL : http://journals.openedition.org/abstractairanica/47463

DOI : 10.4000/abstractairanica.47463

ISBN : 1961-960X

ISSN : 1961-960X

Éditeur :

CNRS (UMR 7528 Mondes iraniens et indiens), Éditions de l'IFRI

\section{Référence électronique}

Rika Gyselen, «Touraj Daryaee. "The Last Ruling Woman of Ërānšahr: Queen Āzarmīgduxt" », Abstracta Iranica [En ligne], Volume 37-38-39 | 2018, document 80, mis en ligne le 30 décembre 2018, consulté le 30 septembre 2020. URL : http://journals.openedition.org/abstractairanica/47463 ; DOI : https:// doi.org/10.4000/abstractairanica.47463

Ce document a été généré automatiquement le 30 septembre 2020.

Tous droits réservés 


\title{
Touraj Daryaee. “The Last Ruling Woman of Ērānšahr: Queen Āzarmīgduxt"
}

\author{
Rika Gyselen
}

\section{RÉFÉRENCE}

Touraj Daryaee. "The Last Ruling Woman of Ērānšahr: Queen Āzarmīgduxt", International Journal of the Society of Iranian Archaeologists, Vol. 1, No. 1, Winter-Spring 2014, p. 77-81

2014

1 Depuis la découverte d'une monnaie d'Āzarmīgduxt par M. I. Mochiri (1972), on n'a cessé de se demander pourquoi cette reine représente sur l'avers de son monnayage l'effigie de son père Khusraw II Parwīz au lieu de la sienne. D'après l'auteur, il faut le voir comme une auto-légitimation d'Āzarmīgduxt confrontée à l'ambition de la grande famille Mihrān. D'après des sources textuelles, Farrox-Ohrmazd, Ėrān-spāhbed de l'Est et de la famille Mihrān, demande la main de la reine pour pouvoir se substituer à elle comme roi de l'empire sassanide. Reste à comprendre pourquoi ses émissions monétaires sont limitées à deux ateliers : WYHC (identifié par Daryaee qui suit Gyselen 1979 : Weh-az-Amid-Kawād dans le nord-ouest du Pārs) et ŠY (souvent identifié à Šīrāz dans le Pārs, bien qu'aucune preuve définitive ne peut en être apportée).

2 On peut regretter une typographie un peu négligée et l'absence d'une illustration d'une monnaie. 


\section{AUTEURS}

RIKA GYSELEN

CNRS, Mondes iranien et indien 